\title{
THE DIVERSIFICATION OF COMMUNES' REVENUE FROM REAL ESTATE ACROSS PROVINCES
}

\author{
Maria Trojanek, prof. \\ Department of Investment and Real Estate \\ Poznań University of Economics and Business \\ e-mail:mariatrojanek@wp.pl

\section{Wojciech Kisiała, PhD} \\ Department of Spatial and Environmental Economics \\ Poznań University of Economics and Business \\ e-mail:wojciech.kisiala@ue.poznan.pl
}

\begin{abstract}
The aim of this paper is to identify the spatial differentiation of revenue from real estate in communes' budgets across Polish provinces. We discuss property fees and taxes which feed into the communes' budgets. We also present the assumptions of the research procedure which enabled us to distinguish classes of provinces according to revenues from real estate. In a further section of the paper, we analyze per capita revenues from real estate and the share of these revenues in the own income of communes among the distinguished classes of distance from the province capital. The results of our study show that, in the years under discussion, there are clear differences between spatial regularities in both scopes of analysis (the level of per capita income from real estate and the share of revenue from properties in the communes' own income).
\end{abstract}

Key words: current revenue, property revenue, asset-related income, cluster analysis, phylogenetic tree.

JEL Classification: C38, H71, H72, R39.

Citation: Trojanek M., Kisiała W., 2016, The Diversification of Communes' Revenue from Real Estate Across Provinces, Real Estate Management and Valuation, Vol. 24, No. 2, pp. 36-49.

DOI: $10.1515 /$ remav-2016-0012

\section{Introduction}

Social and economic changes introduced after 1990, including the marketization of land management and the change of property relations, accelerated the process of the transformation of functional and spatial structures not only of cities, but also of their suburban areas (PARYSEK, WDOWICKA 2002; LISZEWSKI 2006; HARAŃCZYK 2014).

Changes in the spatial structure of cities that have taken place in Poland are similar to ongoing processes in European cities (PARYSEK 2010; MAJER 2009; STRYJAKIEWICZ 2013). The existing differences (in scope and intensity) arise from the determinants of urban development and from the synergic influence of globalization and systemic changes.

The most dynamically developing areas include areas just outside cities and the communes neighboring them. The phenomenon of urban sprawl has various implications, both favorable and unfavorable, in the spatial, environmental, social, economic and financial spheres (PARYSEK, MierZEJEWSKA 2006; PARYSEK 2013; PARYSEK 2006; StAWASZ, BANACHOWICZ 2006; KACZMAREK, MiKUŁA 2011; KOWALEWSKI 2006). 
Demographic changes, depopulation processes, the ageing of the society, the migration of people with a relatively high income and investors (entrepreneurs) seeking better business conditions outside of cities, pose new, unprecedented challenges for local governments. For example: the disparity between the place of work and where one uses services and the place where one pays taxes, leads to, among other things, a loss of revenue from personal income tax (PIT) and corporate income tax (CIT) in the city. At the same time, the city has to finance services of a supralocal character, which the inhabitants of its neighboring communes use as well. The aim of this paper is to identify the spatial diversification of revenues from real estate in communes' budgets across provinces. The study concerns the years 2001 and 2012.

\section{Property as a source of communes' revenue}

The sources of local budget revenue differ largely across countries (CHERNYAVSKY, VARTAPETOV 2004; RUDZKA-LORENTZ, SIERAK 2005; SOCHACKA-KRYSIAK 2008; FAMULSKA 2009; FERNANDEZ MiLAN, CREUTZIG 2016). They usually include:

1) taxes,

2) service fees,

3) transfers within the public finance sector,

4) other income, e.g. from the sale of various assets, from licenses, permits, etc.

Revenues from these sources (2006) constitute different shares in the structure of the communes' income. For example: property taxes are the main source of communes' income in countries such as Australia (38.6\%), Canada (37.8\%), New Zealand (54.5\%) and France (33.7\%). In turn, income from this tax plays a marginal role in the revenue of communes in: the Czech Republic (1.4\%), Finland (2.4\%) Denmark $(3.4 \%)$, Croatia $(3.5 \%)$ or Ukraine $(2,3 \%)$ (UN-HABITAT Report 2009). Income taxes are a more important source of income in Scandinavian countries, where the level of local social expenditure is the highest. For example, in the communes and provinces of Sweden, the revenue from personal income tax was the only (almost 100\%) source of local governments' tax income, while in the communes of Finland and the communes and districts of Denmark, it accounted for 95\% and 90\%, respectively (Finanse... 2004).

There are also distinct differences when it comes to the relation between the revenues to local budgets and transfers within the public finance sector. These transfers are the main source of revenue for a number of communes, although in recent years, we have observed a drop (reduction) in income from this source (Table 1).

Table 1 presents an example of the structure of revenue to the local budgets of selected cities.

Table 1

Income sources of the communes of: Cape Town, Toronto, Madrid and Mumbai

\begin{tabular}{lcccc}
\hline & $\begin{array}{c}\text { Cape Town } \\
\text { 2007-2008 }(\%)\end{array}$ & Toronto 2007 $(\%)$ & Madrid 2003(\%) & $\begin{array}{c}\text { Mumbai } \\
\text { 2007-2008 }(\%)\end{array}$ \\
\hline Property tax & 25.4 & 41.5 & 12 & 19 \\
\hline Other taxes & - & - & 19 & 46 \\
\hline Fees & 40.9 & 21.8 & 16 & 23 \\
\hline Transfers & 25.2 & 20.9 & 39 & 4 \\
\hline Others & 8.5 & 15.8 & 14 & 100 \\
\hline
\end{tabular}

Source: UN-HABITAT Report, Guide to Municipal Finance, Nairobi 2009, p. 21.

The principal acts regulating the issues of communes' revenues in Poland include:

1) The Constitution of the Republic of Poland of 23 April 1997 (Journal of Laws No. 78. Item 483 with later amendments),

2) European Charter of Local Self-Government of 15 October 1985 (Journal of Laws of 1994, No. 124, Item 608), 
3) Act of 27 August 2009 on public finance (Journal of Laws of 2009, No. 157, Item 2140 with later amendments),

4) Act of 13 November 2003 on the revenue of local self-government units (Journal of Laws No. 203, Item 1966 with later amendments.

5) Legal acts providing foundations for raising income by communes also include laws defining the amounts and principles of collecting taxes, especially:

6) The Act of 12 January 1991 on local taxes and fees (consolidated text, Journal of Laws of 27 June 2014, Item 849),

7) Act of 30 October 2002 on forest tax (consolidated text, Journal of Laws of 17 April 2013, Item 465),

8) Act of 15 November 1984 on agricultural tax (consolidated text, Journal of Laws of 26 November 2013, Item 1381).

Among the communes' revenues, a large part of incomes are connected directly or indirectly with real estate management. Properties located in the territory of a commune, belonging to its assets as well as those owned by other entities, constitute the communes' statutory source of revenue. Communes' incomes obtained from real estate management come from different sources and are of a diverse character.

The existing body of literature provides a number of classifications of these revenues (EAGUNA 2002; BorOdO 2004; 2011; PATRZAŁEK 2004; DYLEWSKI, FILIPIAK, GORZAŁCZYŃSKA-KOCZKODAN 2006; RUSKOWSKI, SAEACHNA 2007; CYMERMAN 2009; MISZCZAK 2009; CZEMPAS 2010). From the perspective on issues in our discussion, bearing in mind the way in which real estate income is included in the communes' budgets, we find the criterion which allows us to distinguish two types of revenue most useful, namely:

1) revenue generated by properties owned by a commune,

2) revenue generated by properties owned by entities other than a commune.

The first group of revenues includes:

a) property revenues, such as income from:

- the transformation of perpetual usufruct into the right of ownership,

- the sale of the right of ownership and of the right of perpetual usufruct, including incomes from the sale of properties (apartments, business establishments, land)

b) current revenues, such as fees connected with:

- perpetual usufruct (initial fee and annual fees),

- permanent management,

- use,

- other titles (e.g. easement appurtenant),

- rent and lease.

The adopted classification of revenues generated by communal properties is based on the division of the incomes of local government units into property incomes and current incomes adopted under Art. 165a of the amended Act on public finance. This approach to property incomes is narrower than the one existing before (RUŚKOWSKI, SALACHNA 2007), where the right of ownership and other property rights were the criterion for the division of property incomes.

The other group of revenues, i.e. incomes from properties which are not owned by a commune, includes incomes from:

1) property, agricultural and forest tax,

2) betterment levies,

3) re-zoning fees,

4) inheritance tax and donation tax,

5) tax on civil law transactions.

In the next part of our discussion, we describe in detail only those sources of income which are counted according to the classification of paragraphs, incomes, revenues and resources as separate kinds (paragraphs) of income (ORDINANCE OF THE MinISTER OF FINANCE OF 2 MARCH 2010). Property revenues ${ }^{1}$ included:

1) revenues from the transformation of perpetual usufruct that private individuals are entitled to (paragraph 079),

\footnotetext{
${ }^{1}$ Paragraphs are marked in accordance with the quoted Ordinance
} 
2) revenues from the sale of the right of ownership and the right of perpetual usufruct (Paragraph 077).

Current revenues include revenues from market dues (Paragraph 043) and revenues from fees for management, usufruct and perpetual usufruct (Paragraph 047), as well as income from renting and leasing assets (Paragraph 075).

Property revenues, in turn, refer to income from taxes: property tax (paragraph 031), agricultural tax (paragraph 032) and forest tax (paragraph 033).

The description of other taxes or fees related to real estate, such as the tax on inheritance and donations, tax on civil law transactions, or local fee and resort tax, were intentionally ignored as they were counted together with the kinds of fees (subject to taxations) other than property-related ones, or are indirectly related to real estate (e.g. tax on inheritance and donations).

The aim of this paper is to identify the spatial diversification of revenues from real estate in communes' budgets across the provinces in Poland, both with reference to the size of the population (per capita income from real estate) and with regard to their proportion in the communes' own income (income from real estate as a percentage of their own income reduced by the amount of PIT and CIT).

\section{Assumptions of the research procedure}

In order to analyze the spatial diversification of revenue from real estate feeding into communes' budgets across provinces in Poland, we used a research procedure consisting of four main parts (see Figure 1).

I

\begin{tabular}{|c|} 
The classification of \\
communes in \\
individual \\
provinces on the \\
basis of the \\
distance from the \\
province capital \\
\end{tabular}

II

\begin{tabular}{|c|}
\hline The aggregation of \\
the values of revenue \\
from real estate \\
within the \\
framework of \\
distinguished classes \\
and their relativity \\
with regard to the \\
size of the \\
population and local \\
self-government \\
units' own income \\
(without PIT and \\
CIT) \\
\hline
\end{tabular}

III

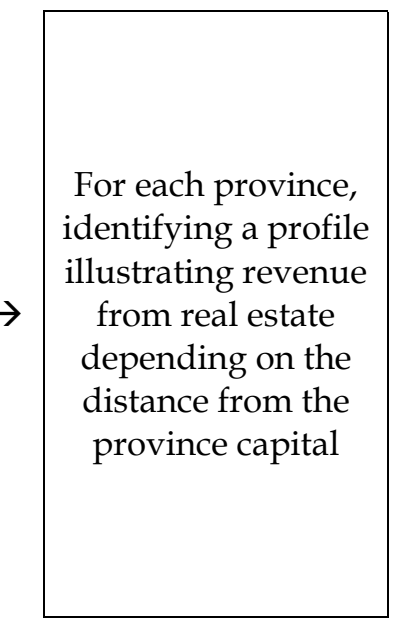

IV

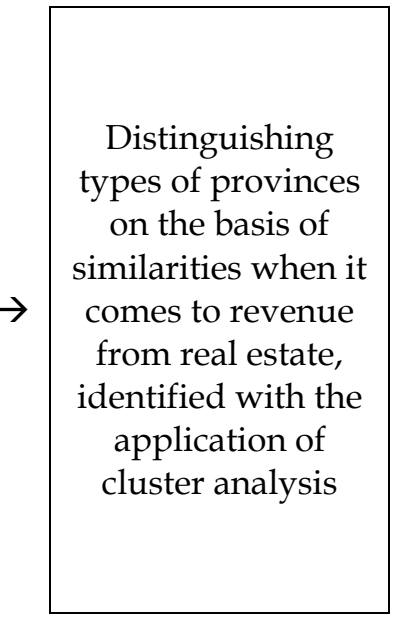

Fig. 1. Research procedure. Source: own study.

At the first stage, using GIS techniques, we measured distances from each commune to the province capital. On this basis, in each province we divided communes into classes. The first class always includes the capital of a province (in the case of Kuyavian-Pomeranian and Lubusz Province, there were two capital cities). The other communes were classified according to a quantile division of $1 / 5$ (the limit values of each class were the quantiles of the distance between a commune and the province capital). In this way, five different classes of distance from a commune to the province capital (II, III, IV, V i VI) were distinguished. Each of them encompassed $20 \%$ of the units in each of the regions.

At the second stage, we gathered data concerning revenues from real estate in the budgets of all local self-government units in Poland in 2001 and 2012. To this end, we used data from annual reports on the execution of budget revenue plan Rb-27S (implemented income), obtained from the Regional accounting Chamber (Polish: Regionalna Izba Obrachunkowa) in Bydgoszcz. Revenues from real estate include:

1) property tax (paragraph 031),

2) agricultural tax (paragraph 032),

3) forest tax (paragraph 033),

4) market dues (paragraph 043), 
5) fees for management, usufruct and perpetual usufruct (paragraph 047),

6) income from renting and leasing assets (paragraph 075),

7) fees for the transformation of perpetual usufruct into the right of ownership that natural persons are entitled to (paragraph 076),

8) the sale of the right of ownership and of the right of perpetual usufruct (paragraph 077).

In a further part of the research, we aggregated the above mentioned amounts of income from real estate within the framework of previously established classes of distance from province capitals. The obtained sums were relativized according to the size of the population of each distance class (calculating the indicator of per capita revenue from real estate), and according to the combined value of the own income of the budgets of communes and cities with county rights for each distance class (calculating the share of income from real estate in self-government units' own income for each class). Relativizing variables (the size of the population according to the actual place of living and the own income of the budgets of communes and cities with county rights) were obtained from the Data Bank of the Main Statistical Office (Polish: Główny Urząd Statystyczny).

The estimated values served as the basis for identifying profiles of the spatial diversification of revenue from real estate depending on the distance from the province capital in each province). Next, we recognized similarities between provinces within the scope of the study. To this end, we applied the procedure of multidimensional grouping called cluster analysis. As part of this analysis, we used the hierarchical grouping method, consisting of iteratively combining objects (provinces) into increasingly large clusters until all objects become one generalized structure referred to as the phylogenetic tree (CORMACK 1971; SZÉKELY, RIZZO 2005; JAWORSKA, MODRANKA 2014). The values of the similitude function - Euclidean distance in this case - were the criterion for combining them. In turn, a method of agglomeration (the principle of joining objects into clusters) was established on the basis of variance analysis with the application of so-called Ward's method. In this method, a point of gravity is determined for each pair of clusters, and the distance between clusters is equal to the sum of squares of deviations of all objects from the determined point of gravity. The procedure of agglomeration with the application of Ward's method aims to minimize the sums of squares of deviations within clusters (WARD 1963; CORMACK 1971; SUCHECKI, LEWANDOWSKA-GWARDA 2010; PANEK, ZWIERZCHOWSKI 2013).

As the outcome of clustering, we obtained phylogenetic trees on the basis of which we distinguished types of provinces that were similar on account of revenues from real estate. Because in the agglomeration procedure of cluster analysis the number of groups is not predetermined, the division into groups (types of provinces) was made on the basis of the chart of the agglomeration process (the plot of linkage distance across steps), which presents differences between clusters that arise in the consecutive steps of the analysis (STANISZ 2006; PANEK, ZWIERZCHOWSKI 2013).

\section{The analysis of per capita revenue from real estate}

The analysis of profiles of per capita revenues from real estate in the distinguished classes of distance from province capitals in 2001 and 2012 (see: Fig. 2) shows that, in the period under study, these values increased significantly. In turn, the course (shape) of particular profiles changed to a much lesser degree, which proves that per capita revenues from real estate basically increase proportionally in each distance class. The biggest differences in the course of profiles illustrating the years 2001 and 2012 were observed in Lubusz, Lublin, Podlaskie, Pomeranian and West Pomeranian Province.

In most provinces (12 in 2001 and 13 in 2012), it was Class I - including capital cities of provinces that generated the highest amounts of revenue. The opposite situation (the highest values in the furthest distance classes, i.e. V and VI) was observed in two provinces in 2001 (Kuyavian-Pomeranian and Świętokrzyskie), and in one in 2012 (Lubusz). In turn, the highest values in intermediary classes (II and IV) were observed in two cases, both in 2001 (Łódź and Lublin), and in 2012 (Łódź and West Pomeranian). In the Kuyavian-Pomeranian Province, the class generating the highest revenue from real estate (Class V) included, among others, such units as Włocławek and Grudziądz, while in the Świętokrzyskie Province (class VI) - among others, Ożarów, Połaniec and Sandomierz. The high position of Class V in 2012 in the Lubusz Province was due to the presence of industrial centers - Żary and Kostrzyn nad Odrą and tourist resorts - Łagów and Pszczew. What had a considerable impact on the course of the analyzed profiles and dominance of Class IV in the Łódź Province was the fact that it includes communes benefiting from the Bełchatów coal mine (e.g. Kleszczów, Szczerców). The highest position of Class III in Lublin Province in 2001 was due to the communes with industrial- 
manufacturing and touristic functions (e.g. Puławy, Rejowiec Fabryczny, Krasnystaw, Kazimierz Dolny). Finally, the characteristic course of the profile in West Pomeranian Province in 2012 may be justified by high revenues from real estate in coastal touristic communes, such as Rewal, Dziwnów or Trzebiatów, which belong to Class IV of the distance from the province capital - Szczecin.
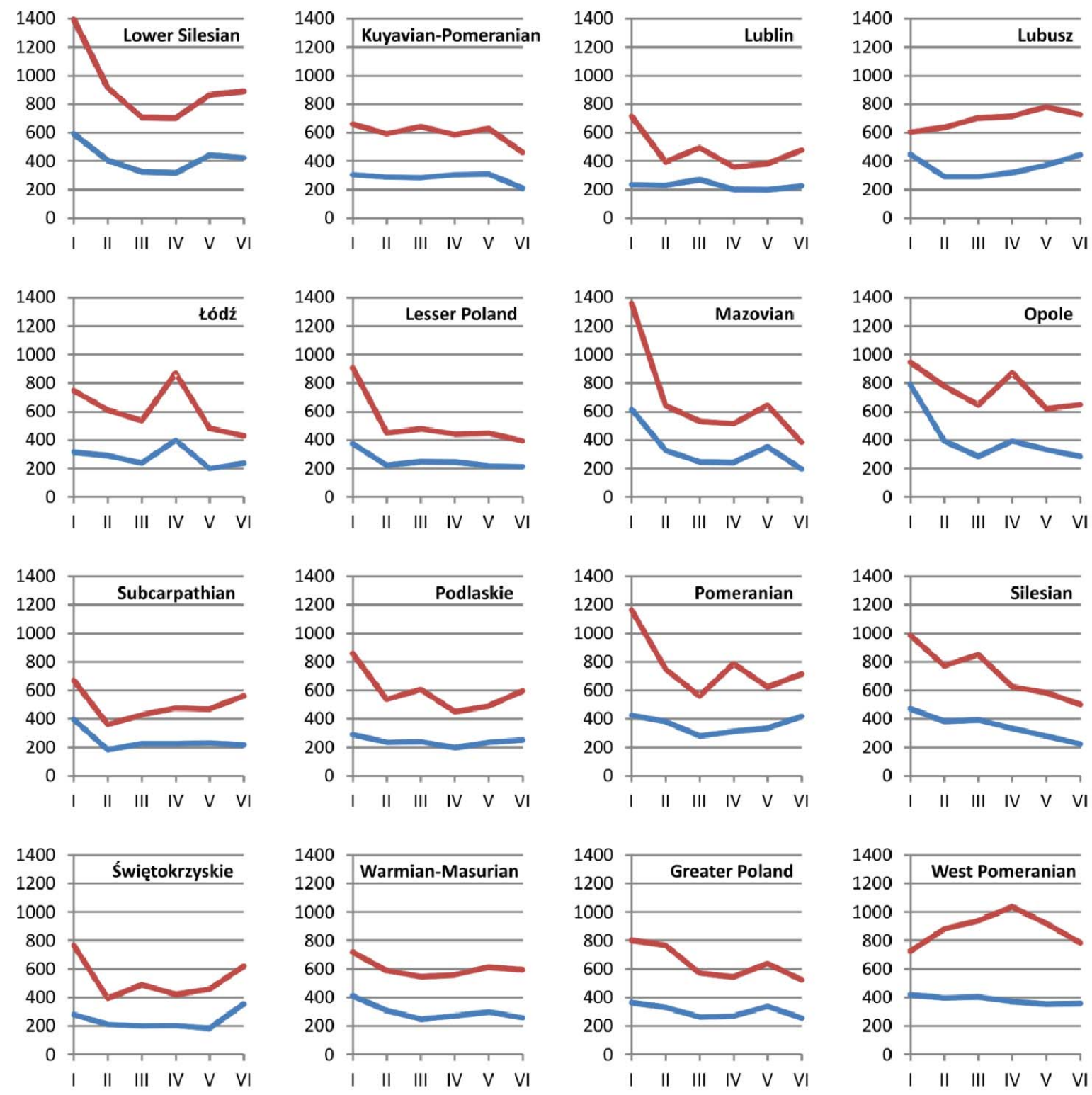

Fig. 2. Revenue from real estate (in Polish zloty per capita) in the budgets of local self-government units according to the class of distance from the province capital (2001 - blue line, 2012 - red line). Source: own study.

Analyzing the above profiles, we should also pay attention to the unproprotional increases of per capita revenue from real estate in the capitals of the following provinces: Lower Silesian - Wrocław, Lublin - Lublin, Lesser Poland - Kraków, Mazovian - Warsaw, Podlaskie - Białystok, Pomeranian Gdańsk and Świętokrzyskie - Kielce. What we can notice here is the fact that central areas tended to grow faster than peripheral ones, which led to the polarization of the economic growth in space.

On the basis of data concerning per capita revenues from real estate in the particular distance classes, we carried out the cluster analysis, which enabled us to distinguish - based on the similarity of profiles - as homogeneous groups (types) of provinces in 2001 and 2012 as possible.

In the period under study (2001), the cluster analysis indicated four groups of provinces with similar characteristics as regards per capita revenue from real estate in the particular classes of distance from the province capital (see: Fig. 3 and 4). The first type (A) included the following 
provinces: West Pomeranian, Silesian, Pomeranian and Lower Silesian. These were mostly regions located near the western, northern and southern borders of Poland. A large part of them were the socalled "recovered territories", i.e. the territories that became part of Poland after World War II. The second group (B) consisted of the Opole and Mazovian Province. This type of regions was characterized by a significant dominance of the central city over the other areas (commune classes) as far as revenue from real estate was concerned. The third group (C) comprised provinces of central and northern Poland - Greater Poland, Warmian-Masurian, Kuyavian-Pomeranian, and Łódź. Distinguishing this type was the lack of a clearly dominant class in the scope under analysis and the sinusoidal course of profiles. The last group (D) consisted of provinces of eastern and south-eastern Poland, including Świętokrzyskie, Podlaskie, Lublin, Subcarpathian and the Lesser Poland Province.

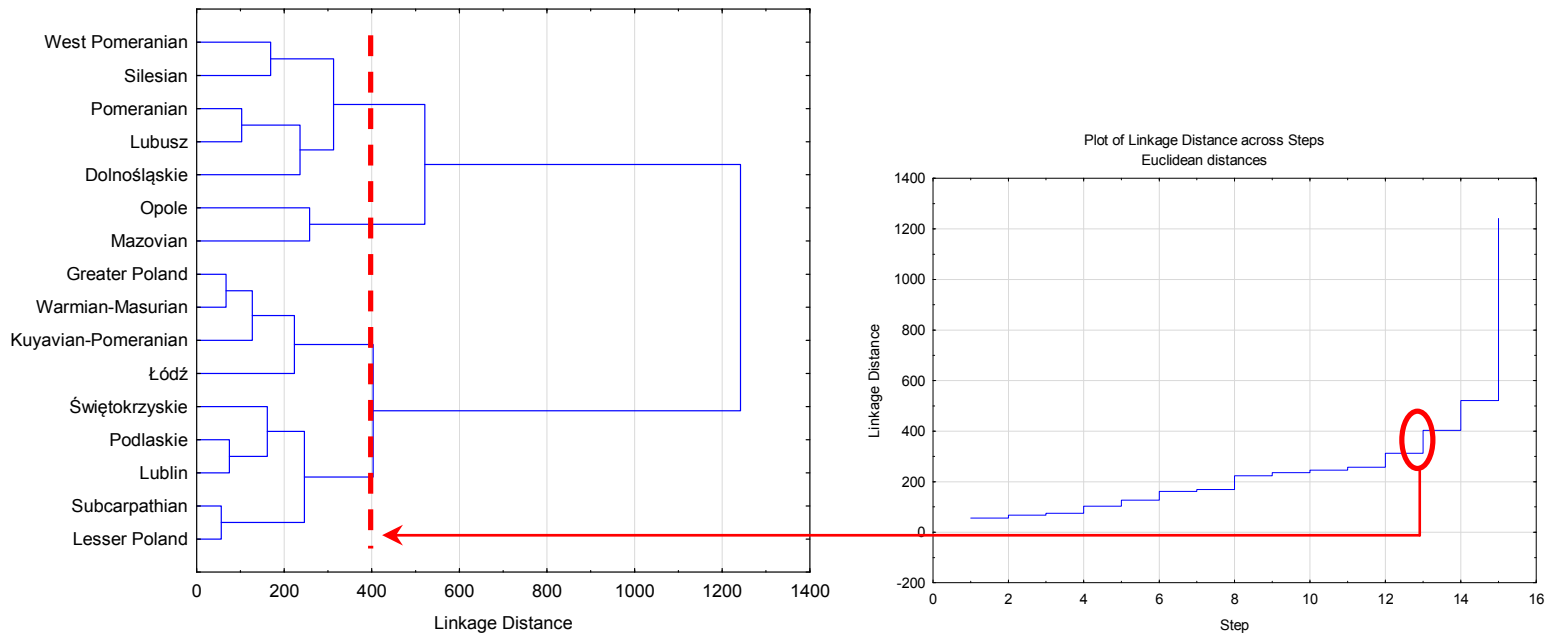

Fig. 3. The phylogenetic tree of province profiles referring to the relations between revenue from real estate (in Polish zloty per capita) in the budgets of local self-government units and the class of distance from the province capital in 2001. Source: own study.

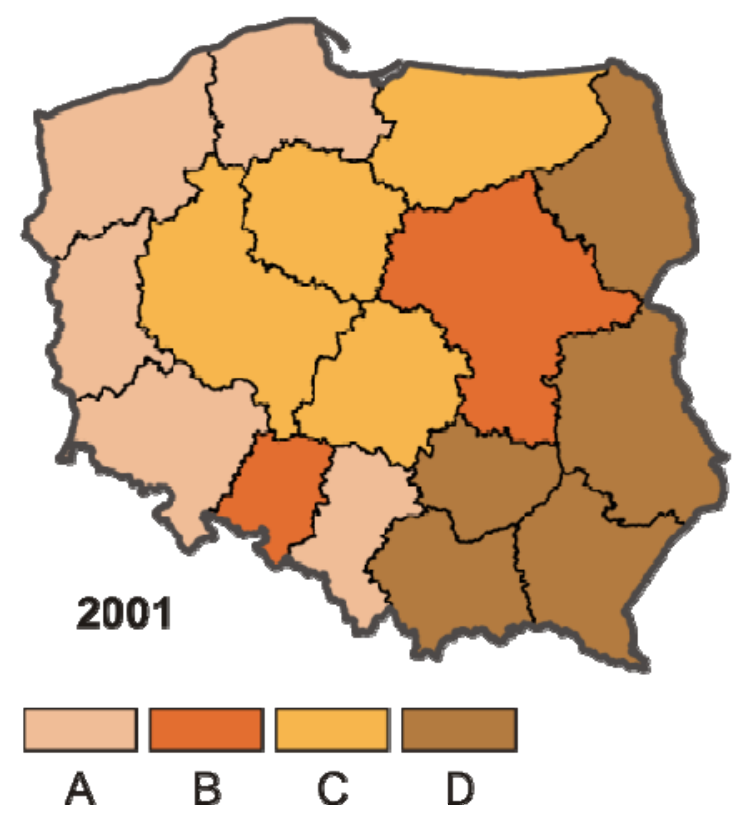

Fig. 4. Groups of provinces distinguished on the basis of cluster analysis (data for 2001). Source: own study.

The analogical study carried out on the basis of data from 2012 showed changes in the categorization of individual provinces in the particular provinces (see: Fig. 5 and 6). Nevertheless, we were still able to identify some spatial regularities with respect to similarities between regional profiles of per capita revenue from real estate. 
The fact that the profile of West Pomeranian Province was different than all the others led to the establishment of a single-element type - A. The second type (B) included the Silesian, Pomeranian, Opole, Masovian, and Lower Silesian Provinces. In these provinces, we can observe the clear dominance of the capital over other areas and the diversification of the other commune classes as far as positions were concerned. The third group (C) consisted of the provinces of central, western and northern Poland - Greater Poland, Warmian-Masurian, Kuyavian-Pomeranian, Lubusz and Łódź. These provinces were characterized by lower per capita revenues from real estate (basically not exceeding 800 zloty/person) and the diversified course of profiles. Finally, the fourth type (D) included, as in 2001, provinces located in the east and south-east of Poland, i.e.: Świętokrzyskie, Subcarpathian, Lublin, Podlaskie and Lesser Poland.

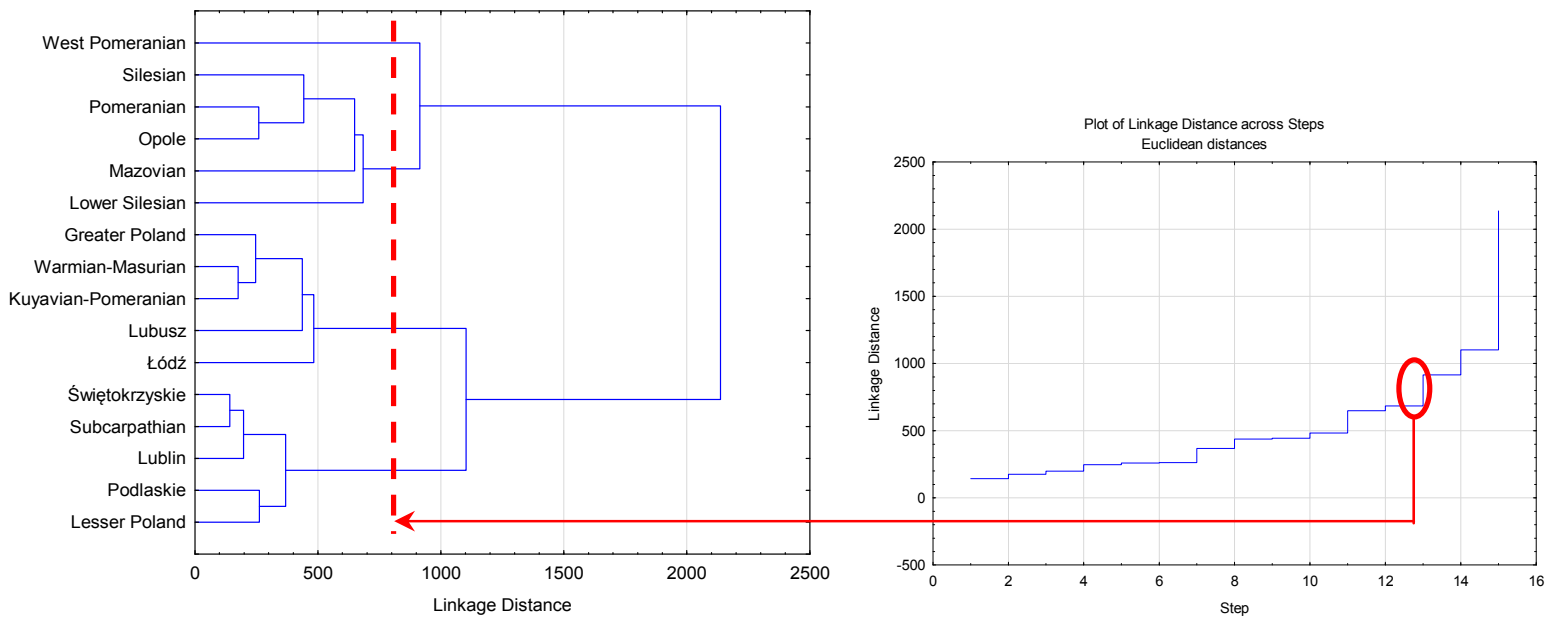

Fig. 5. The phylogenetic tree of province profiles referring to the relations between revenue from real estate (in Polish zloty per capita) in the budgets of local self-government units and the class of distance from the province capital in 2012. Source: own study.

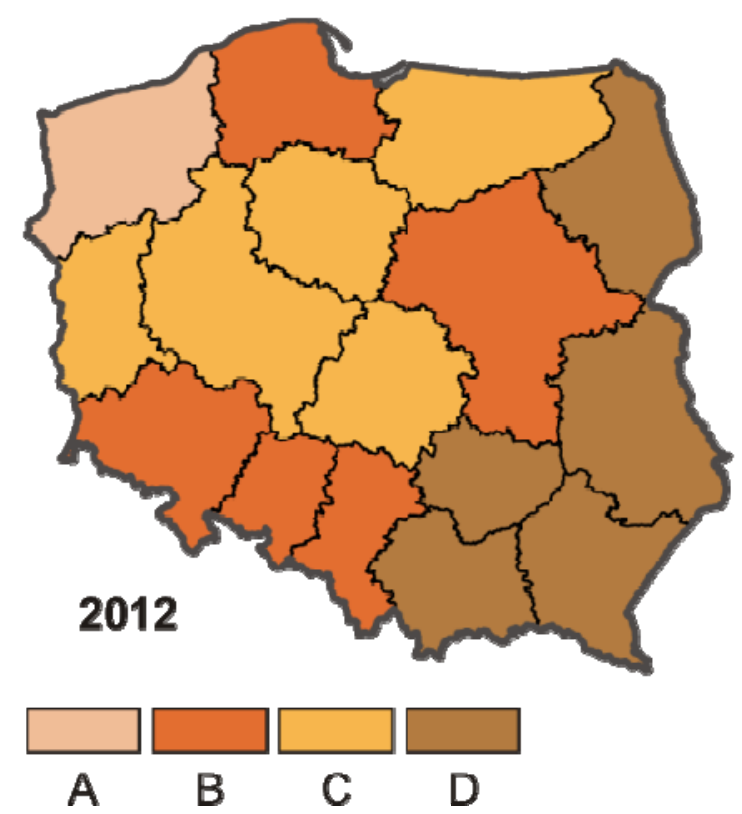

Fig. 6. Groups of provinces distinguished on the basis of cluster analysis (data for 2012). Source: own study. 


\section{The analysis of revenue from real estate with regard to local self-government units' own income ${ }^{2}$}

The comparison of profiles established in the first part of the analysis (per capita revenue from real estate) with those illustrating the share of revenue in communes' own income in the consecutive classes of distance from the province capital (see: Fig. 7) shows:

1) significantly smaller differences between the analyzed years (2001 and 2012) in the cases of the second analysis (the study of proportion),

2) an entirely different course of the established profiles, thus - of spatial regularities, in both analyses.
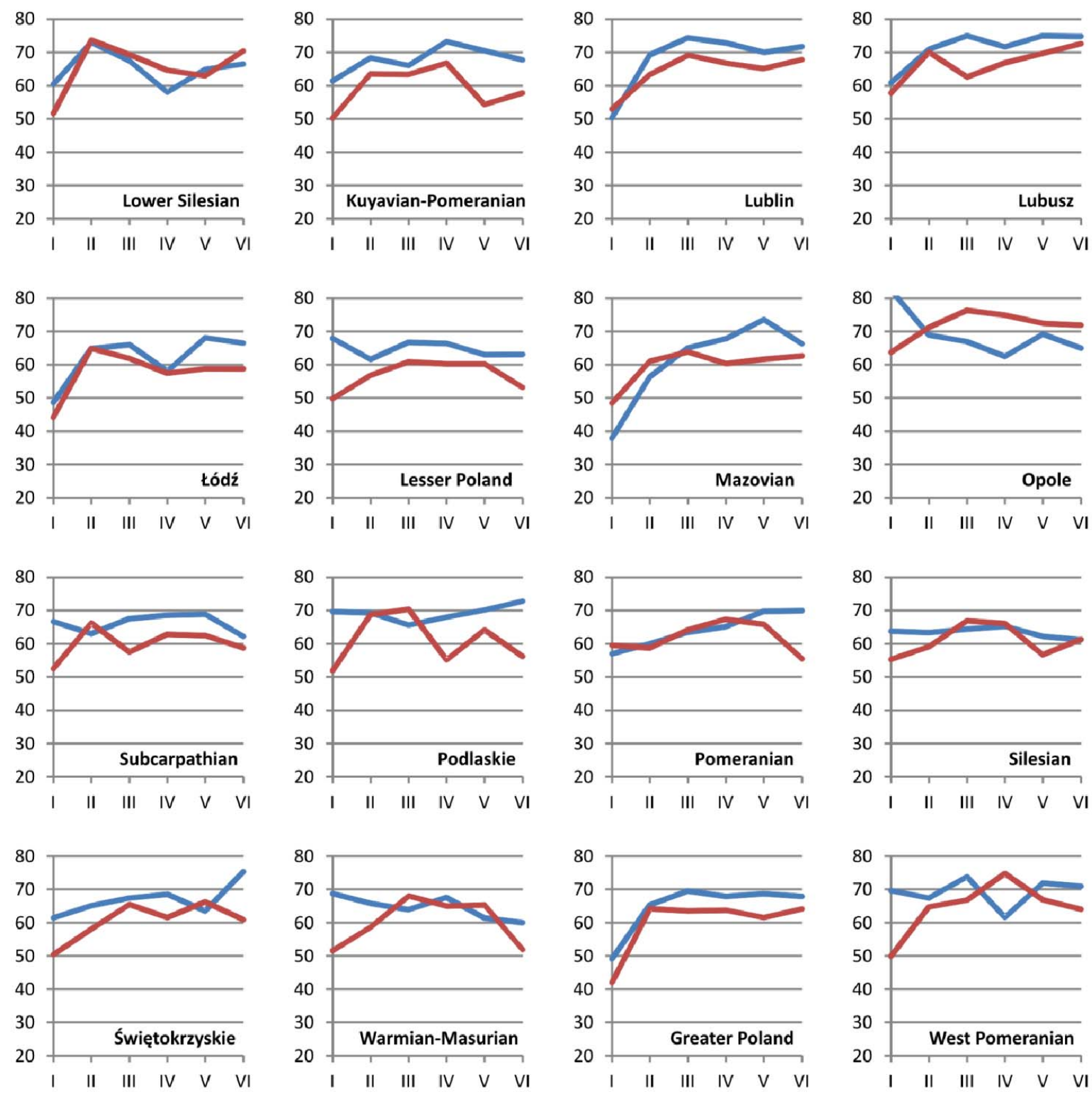

Fig. 7. Revenue from real estate (in Polish zloty per capita) in the budgets of local self-government units (reduced by PIT and CIT) according to the class of distance from the province capital (2001 blue line, 2012 - red line); values of axes OY expressed in \%. Source: own study.

A characteristic feature of the course of profiles illustrating the share of revenue from real estate in the self-government units' own income in the majority of provinces is a drop of values in 2012 as compared to 2001 (Kuyavian-Pomeranian, Lublin, Łódź, Lesser Poland, Subcarpathian, Greater Poland, West Pomeranian). In some provinces, the course of the analyzed profiles remained

2 As it was mentioned earlier, own income was reduced by the income of communes from personal income tax (PIT) and corporate income tax (CIT). In a further part of the study, this sequence was not repeated. 
practically unchanged (Lower Silesian, Lublin, Pomeranian, Greater Poland).

Another specific feature of the examined profiles was the lower level of values pertaining to province capitals (class I) in relation to other distance classes. While, in 2001, only eight provinces were characterized by the lowest values in Class I, this number grew to 15 in 2012. The reason for this was the fact that the structure of self-government units' own income in big cities (including province capitals) is becoming more and more diverse, and revenue from real estate does not play as significant of a role in this group as in small urban, urban-rural and rural communes.

Analyzing the course of profiles reflecting the share of revenue from real estate in the own income of self-government units, we must also pay attention to its irregularity (diversification) in different distance classes. This is signified by the lack of a clear relation between revenue from real estate expressed in the form of the percentage of the budget and distance from the province capital.

In the case of the analysis of similarities between the provinces in the scope under study, based on the data from 2001, the chart of the phylogenetic tree showed three distinct clusters (see: Fig. 8 and 9).

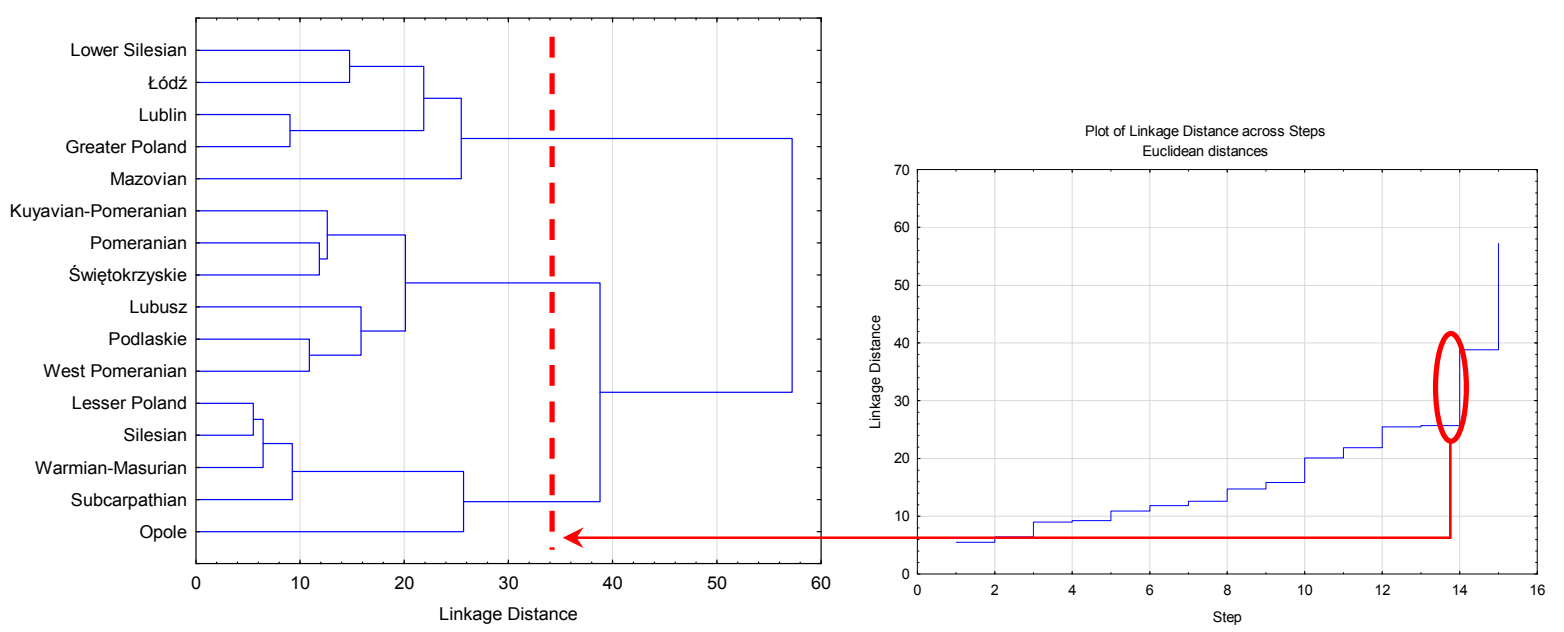

Fig. 8. The phylogenetic tree of province profiles referring to the relations between the share of revenue from real estate in local self-government units' own income (reduced by PIT and CIT) and the class of distance from the province capital in 2001. Source: own study.

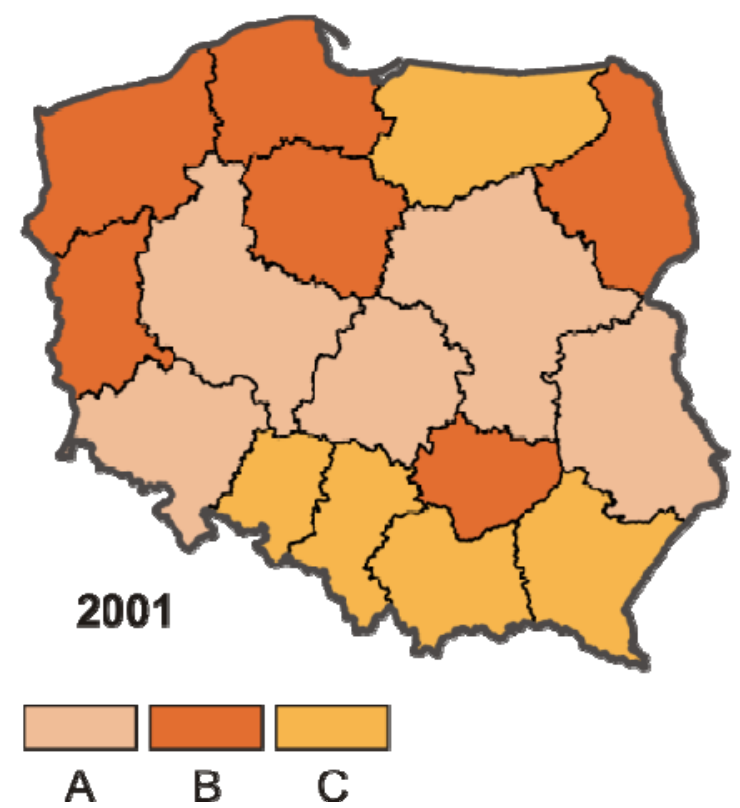

Fig. 9. Groups of provinces distinguished on the basis of cluster analysis (data from 2001). Source: own study.

The first group (A) consisted of Lower Silesian, Łódź, Lublin, Greater Poland and Mazovian Province, i.e. a belt of provinces spreading from the west to the east of the country. What is a 
characteristic feature of this group is the low share of revenue from real estate in the province capital and differences in the course of profiles in the consecutive distance classes. The second group (B) included the following provinces: Kuyavian-Pomeranian, Pomeranian, Świętokrzyskie, Lubusz, Podlaskie, and West Pomeranian. These were mostly provinces located in the northern part of Poland. It was difficult to spot any similarities of profiles in this group, except for generally high values attributed to the consecutive distance classes (around 70\%). The next group (C) comprised Lesser Poland, Silesian, Warmian-Masurian, Subcarpathian and Opole Province, thus - except for the Warmian-Masurian Province - they were all regions of southern and south-east Poland. A specific feature of this type of provinces was a relatively low share of revenue from real estate in local selfgovernment units' income (below 70\%) and their low diversification across classes.

Cluster analysis based on data from 2012 enabled us to distinguish four groups of provinces (see: Fig. 10 and 11). The first group (A) consisted of provinces at the western border of the country -Lower Silesian, Lubusz and West Pomeranian - as well as Lublin Province in the east. In this group, we could observe low values in the first class (capitals) and a general growth trend in the subsequent classes. The second group (B) included the Opole Province, which, because of very high values in Class I - with the capital in Opole - did not fit in with any other distinguished types of provinces. The third group (C) consisted of provinces in northern Poland, i.e.: Kuyavian-Pomeranian, Pomeranian, and Warmian-Masurian, as well as the Silesian Province in the south. It is difficult to identify any clear regularities between the analyzed values in this group of regions. Finally, the last group (D) comprised the following provinces: Łódź, Greater Poland, Lesser Poland, Subcarpathian, Mazovian, Świętokrzyskie, and Podlaskie. They were all characterized by low values in Class I and significant differences between values identified in Classes I and II.

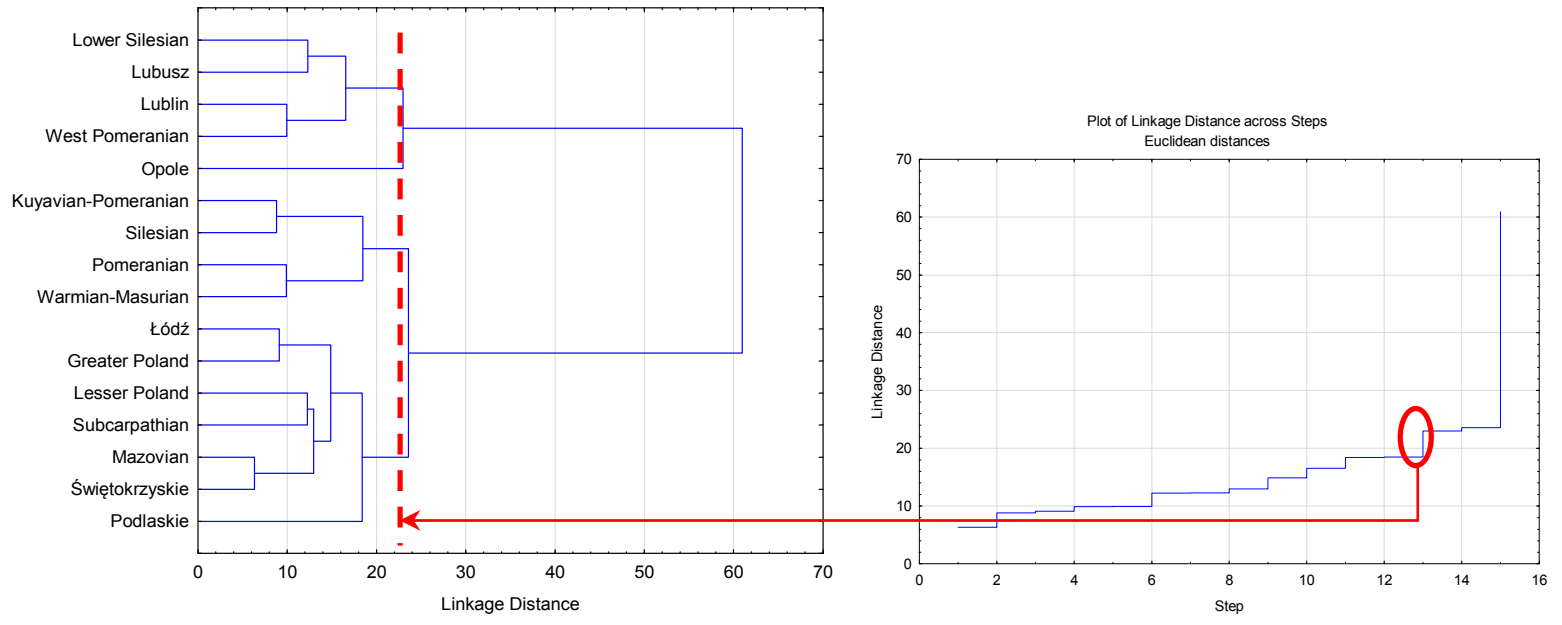

Fig. 10. The phylogenetic tree of province profiles referring to the relations between the share of revenue from real estate (reduced by PIT and CIT) in local self-government units' own income and the class of distance from the province capital in 2012. Source: own study.

\section{Conclusions}

Our research shows that in the years under analysis:

1) the capital cities of provinces obtained the highest per capita revenues from real estate,

2) over-proportionate growths of per capita revenue from real estate were observed in Wrocław, Lublin, Kraków, Białystok, Gdańsk and Kielce,

3) the highest values of this indicator were also marked in other distance classes than Class I (province capitals). The selected classes owed their high position to the presence of industrial centers, coal mines, or touristic areas in the areas belonging to them.

The distinguished province profiles (per capita revenue from real estate) indicate growth and significant differences between the analyzed years.

In turn, the course of province profiles reflecting the share of revenue from real estate in local selfgovernment units' own income shows:

1) a drop in this proportion in most provinces when compared to 2001,

2) lower values of this proportion in the case of province capitals, 
3) considerable differences between the course of profiles in the consecutive classes of distance, which signifies the lack of distinct relations between distance and the value of this indicator.

The decreasing share of revenue from real estate in self-government units' own income is evidence of the diversification of communes' own income and of the reduction of the share of revenue from real estate in their budgets.

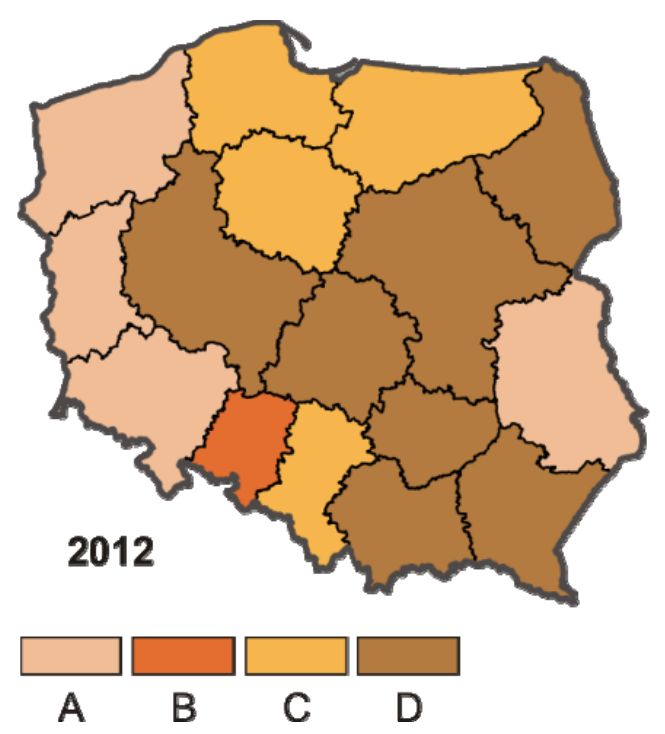

Fig. 11. Groups of provinces distinguished on the basis of cluster analysis (data from 2012). Source: own study.

\section{References}

Borodo A., 2004, Samorzad Terytorialny. System prawno-finansowy (Territorial Self-government. The Legalfinancial System), LexisNexis, Warsaw.

BORODO A., 2011, System finansowy samorzadu terytorialnego w Polsce (The Financial System of a Territorial Self-government in Poland), Dom Organizatora TNOiK, Torun.

CHERNYAVSKY A., VARTAPETOV K., 2004, Municipal Finance Reform and Local Self-governance in Russia, Post-Communist Economies, 16 (3), pp. 251-264.

CORMACK R.M., 1971, A Review of Classification, Journal of the Royal Statistical Society, Series A, 134(3), 321-367.

CYMERMAN J., 2009, System opłat od nieruchomości. Aspekty teoretyczne i prawne (System of Property-related Fees. Theoretical and Legal Aspects), Educaterra, Olsztyn.

CZEMPAS J., 2010, Udział podatku od nieruchomości w budżetach gmin województwa śląskiego (Share of Property Tax in the Budgets of Communes in the Silesian Province), Wiadomości Statystyczne (Statistical News) No. 6.

DYLEWSKI M., FILIPIAK B., GOŁACZYŃSKA-KOCZKODAN M., 2006, Finanse samorządowe. Narzędzia. Decyzje. Procesy (Self-government Finances. Tools. Decisions. Processes), Polska Akademia Nauk (Polish Academy of Sciences), Warsaw.

Fernandez Milan B., Creutzig, F., 2016, Municipal Policies Accelerated Urban Sprawl and Public Debts in Spain, Land Use Policy, 54, pp. 103-115.

Finanse samorządów terytorialnych w Europie (Finances of Territorial Self-governments in Europe), 2004, Dexia, Warsaw-Paris.

HARAŃCZAK A., 2014, Zmiany w użytkowaniu gruntów w największych miastach Polski (Changes in Land use in the Largest Polish Cities), (in:) Gospodarowanie przestrzenia miast i regionów - uwarunkowania $i$ kierunki (Spatial Management of Cities and Regions - Conditions and Directions), eds. KuDŁACZ T., LITYŃSKI P., The Committee on Spatial Economy and Regional Planning of the Polish Academy of Sciences, p. 303.

JAWORSKA R., MODRANKA E., 2014, Metody opisowej statystyki przestrzennej oraz wybrane zagadnienia eksploracyjnej analizy danych przestrzennych (Methods of Descriptive Spatial Statistics and Selected Issues 
of Explorative Spatial Data Analysis) , pp. 111-144, (in:) Statystyka przestrzenna. Metody analiz struktur przestrzennych (Spatial Statistics. Methods of Spatial Structure Analyses), ed. SucHECKA J., Wydawnictwo C.H.Beck, Warsaw.

KACZMAREK T., MiKUŁA Ł., 2011, Spójność terytorialno-administracyjna aglomeracji poznańskiej (TerritorialAdministrative Cohesion of the Poznan Agglomeration), Bogucki Wydawnictwo Naukowe ("Bogucki" Scientific Publishers), Poznań, pp. 7-8.

KoWALEWSKI A.T., Społeczne, ekonomiczne i przestrzenne bariery rozwoju zrównoważonego (Social, Economic and Spatial Barriers of Sustainable Development), Instytut Rozwoju Miast (Institute of Urban Development), Kraków, 2006, p. 44 ff.

LISZEWSKI P.P., 2006, Nowe przestrzenie w miastach (na obszarach zurbanizowanych) (New Spaces in Cities (in Urbanized Areas)), (in:) Nowe przestrzenie w mieście. Ich organizacja i funkcje (New Spaces in the City. Their Organization and Function), ed. JAŻDŻEWSKA I., Wydawnictwo Uniwersytetu Łódzkiego (Lodz University Press), Łódź, pp. 41.

ŁAGUNA T.M., 2002, Aktywne gospodarowanie nieruchomościami szansa zwiększenia wptywów dla budżetów gmin (Active Real Estate Management an Opportunity for Increasing Revenues of Commune's Budgets), (in:) Finanse publiczne w skali lokalnej (Public Finances on a Local Scale), ed. ADAMOWICZ M., Wydawnictwo SGGW, Warsaw.

MAJER A., 2009, Wspótczesna urbanizacja, przemiany i szanse rozwoju (Modern-day Urbanization, Changes and Opportunities for Development), (in:) Człowiek-miasto-region. Zwiazki i interakcje (Man-City-Region. Relationships and Interactions), ed. GORZELAK G., SZCZEPAŃSKI M., ŚLĘŻAK-TAZBIR W., Wydawnictwo Naukowe Scholar, Warsaw, p. 252.

MiszczUK M., 2009, System podatków i opłat samorządowych w Polsce (System of Self-government Taxes and Fees in Poland), C.H. Beck, Warsaw.

PANEK T., ZWIERZCHOWSKI J., 2013, Statystyczne metody wielowymiarowej analizy porównawczej (Statistical Methods of Multi-Diementional Comparative Analysis), Oficyna Wydawnicza SGH (Warsaw School of Economics Press), Warsaw.

PARYSEK J.J., 2006, Miasta polskie w procesie globalizacji (Polish Cities in the Process of Globalization) (in:) Kierunki przekształcen struktury gospodarczej $i$ społeczno-demograficznej miast (Directions of Changes in the Economic and Socio-demographic Structure of Cities), eds. SŁODARCZYK J., SZAFRANEK E., Wydawnictwo Uniwersytetu Opolskiego (University of Opole Press), Opole, p. 29.

PARYSEK J.J., 2010, Aglomeracja poznańska: wybrane problemy rozwoju i funkcjonowania (Poznan Agglomeration: Selected Developmental and Operational Problems), (in:) Wyzwania i kierunki rozwoju aglomeracji poznanskiej (Challenges and Directions of the Development of the Poznan Agglomeration), Bogucki Wydawnictwo Naukowe, Poznań, pp. 17.

PARYSEK J.J., 2013, Polityka miejska i wspótczesne problemy funkcjonowania i rozwoju miast polskich (Urban Policy and Current Operational Problems in the Development of Polish Cities) (in:) Dynamika, cele $i$ polityka zintegrowanego rozwoju regionów. Aspekty teoretyczne i zarzadzanie w przestrzeni (Dynamics, Goals and Policy of the Integrated Development of Regions), ed. GACZEK W.M., Bogucki Wydawnictwo Naukowe, Poznań, p. 87.

PARYSEK J.J., MierzejEWSKa L., 2006, Poznań, Cities, 23 (4), pp. 291-305.

PARYSEK J.J., WDOWICKA M., 2002, Polish Socio-economic Transformation: Winners and Losers at the Local Level, European Urban and Regional Studies, 9 (1), pp. 73-80.

PATRZAŁEK L., 2004, Finanse samorzadu terytorialnego (Finances of the Territorial Self-Government), Wydawnictwo Akademii Ekonomicznej we Wrocławiu (Wroclaw Academy of Economics Press), Wrocław.

Regulation of the Minister of Finance on the detailed classification of incomes, expenses, revenues and expenses, as well as funds from foreign sources, Journal of Laws 2010, No. 38, Item 207.

RuŚKOWSKI E., SAŁACHNA J.M., 2007, Finanse lokalne po akcecji (Local Finances after Accession), 2nd ed., Wolters Kluwer Business, Warsaw.

STANISZ A., 2006, Przystępny kurs statystyki z zastosowaniem STATISTICA PL na przykładach z medycyny (Comprehensible Course in Statistics Using STATISTICA PL on Examples from Medicine), Vol. 3, Wydawnictwo StatSoft Polska, Kraków.

STAWASZ D., BANACHOWICZ B., 2006, Przyczyny i następstwa rozlewania się miast - przykład Łodzi (Causes and Consequences of Urban Sprawl), (in:) Kierunki transformacji społeczno-ekonomicznej przestrzeni Polski ze szczególnym uwzzlędnieniem obszarów metropolitalnych II (Directions of Socio-economic Transformations of Polish Space with Particular Attention Given to II Metropolitan Areas), ed. WILK K., 
PotoczNA I., Wydawnictwo Akademii Ekonomicznej we Wrocławiu (Wroclaw Academy of Economics Press), Wrocław, p. $271 \mathrm{ff}$.

STRYJAKIEWICZ T., 2013, Proces kurczenia się miast (urban shrinkage) i jego konsekwencje (The Process of Urban Shrinkage and its Consequences), (in:) Dynamika, cele i polityka zintegrowanego rozwoju regionów Aspekty teoretyczne $i$ zarzadzanie w przestrzeni (Dynamics, Aims and Policy of Integrated Regional Development. Theoretical Aspects and Spatial Management) ed. GACZEK W.M., Wydawnictwo Naukowe Bogucki ("Bogucki" Scientific Publishing), Poznań, p. 126.

SUCHECKI B., LEWANDOWSKA-GWARDA K., 2010, Klasyfikacja, wizualizacja i grupowanie danych przestrzennych (Classification, Visualization and Grouping of Spatial Data), pp. 37-69, (in:) Ekonometria przestrzenna. Metody i modele analizy danych przestrzennych (Spatial Econometrics. Methods and Models of Spatial Data Analysis), ed. SuCHECKI B., Wydawnictwo C.H.Beck (C.H. Beck Publishing), Warsaw.

SZÉKELY G.J., RIZZO M.L., 2005, Hierarchical Clustering via Joint Between-Within Distances: Extending Ward's Minimum Variance Method, Journal of Classification, 22, pp. 151-183.

UN-HABITAT Report, 2009, Guide to Municipal Finance, Nirobi.

WARD J.H., 1963, Hierarchical Grouping to Optimize an Objective Function, Journal of the American Statistical Association, 58, pp. 236-244. 